Jurnal Penelitian Hasil Hutan

Forest Products Research Journal

Vol. 13 No. 3 (1995) pp. 94 - 100

\title{
PRODUKTIVITAS DAN EFISIENSI PEMANENAN KAYU DENGAN TEKNIK PENEBANGAN POHON SERENDAH MUNGKIN DI HUTAN PRODUKSI ALAM : STUDI KASUS DI TIGA PERUSAHAAN HUTAN DI KALIMANTAN TENGAH
}

(The productivity and efficiency of wood harvesting by practicing the lowest possible felling technique :a case study in three logging companies in Central Kalimantan)

\section{Oleh/By :}

\section{Maman Mansyur Idris \& Sona Suhartana}

Summary

This paper presents the results of the study of wood harvesting productivity and efficienc) when practicing the lowest possible felling technique. The case study was selected in three logging companies in Central Kalimantan in 1994. Then, the results are compared to those obtained from conventional felling technique.

The results of the study are as follow:

1. The average of wood harvesting productivity is $25,2 \mathrm{~m}^{3} / \mathrm{hr}$ for lowest possible felling technique and $28,8 \mathrm{~m}^{3} / \mathrm{hr}$ for conventional felling. This difference is statistically significant.

2. The average of wood harvesting efficiency is $86,1 \%$ for lowest possible felling technique and $82,1 \%$ for conventional felling technique. This difference of $1,28 \mathrm{~m}^{3} / \mathrm{tree}$ is hight. significant.

3. The average of stump height when practicing the lowest possible felling technique is $0,45 \mathrm{~m}$, while for conventional felling technique is $1,21 \mathrm{~m}$.

\section{PENDAHULUAN}

Suatu langkah baru di bidang teknik penebangan pohon di hutan produksi alam di Indonesia dewasa ini telah mulai dirintis. Teknik penebangan pohon yang sebelumnya memperkenankan ketinggian tunggak sampai dua meter, diubah menjadi ketinggian tunggak serendah mungkin atau bila memungkinkan rata dengan tanah. Langkah ini menjadi kuat segi hukumnya karena arahan pelaksanaannya dicantumkan dalam lampiran Surat Keputusan Direktur Jenderal Pengu sahaan Hutan Nomor 151/Kpts/IV-BPHH/1993 tanggal 19 Oktober 1993 tentang Petunjuk Teknis Tebang Pilih Tanam Indonesia (TPTI) pada hutan alam daratan (Direktorat Jenderal Pengusahaan Hutan, 1994). 
Langkah Ini dianggap suatu kemajuan karena acuan mengenai teknik penebangan sebelumnya masih memperkenankan tinggi tunggak yang relatif masih tinggi. Sebagai teladan, Wenger (1984) menganjurkan tinggi tunggak sampai sepertiga dari diameter setinggi dada untuk pohon yang tidak berbanir. Sedangkan untuk pohon yang berbanir, ţinggi tunggak yang masih diizinkan disepakati sampai dengan tinggi banirnya.

Langkah terobosan ini pada hakekatnya merupakan salah satu realisasi dari upaya peningkatan efisiensi pemanenan kayu. Dengan menebang pohon serendaks mungkin, dapat diharapkan bagian kayu yang dapat dimanfaatkan menjadi lebih banyak, karena bagian kayu yang biasanya tertinggal di tunggak sebagai limbah, juga dapat dimanfaatkan.

Upaya peningkatan efisiensi pemanfaatan kayu dengan mengubah teknik penebangan tersebut, nampaknya tidak akan memasyarakat, apabila tidak memiliki cukup bukti bahwa penerapannya menghasilkan dampak positif dalam kegiatan pemanfaatan sumberdaya hutan. Oleh karena itu suatu uji coba perlu dilakukan di lapangan.

Penelitian ini bertujuan untuk mengetahui pengaruh dari penerapan teknik penebangan serendah mungkin terhadap produktivitas kerja pemanenan kayu dan efisiensi pemanenan kayunya. Di samping itu, penelitian ini juga bertujuan untuk mengetahui tinggi tunggak terendah yang masih dapat dicapai oleh penebangan serendah mungkin.

\section{METODE PENELITIAN}

\section{A. Waktu, Lokasi dan Peralatan}

Penelitian dilaksanakan pada bulan September 1994 di tiga areal Hak Pengusahaan Hutan (HPH), yaitu HPH A yang termasuk ke dalam wilayah Cabang Dinas Kehutanan (CDK) Barito Hulu sedangkan HPH B dan C termasuk ke dalam wilayah CDK Barito Tengah. Menurut administrasi pemerintahan, HPH A termasuk ke dalam wilayah kabupaten Puruk Cahu sedangkan HPH B dan C termasuk ke dalam wilayah kabupaten Muarateweh. Ketiga HPH ini termasuk ke dalam wilayah propinsi Daerah Tingkat I Kalimantan Tengah.

Ketiga areal penelitian umumnya memiliki kelerengan lapangan berkisar antara $18 \%-25 \%$ dengan ketinggian tempat antara 25 meter sampai 18 meter dari permukaan laut. Keadaan tegakan yang didominasi oleh jenis-jenis dari famili Dipterocarpaceae memiliki kerapatan antara 174 -196 pohon/Ha (untuk pohonpohon dengan diameter $20 \mathrm{~cm}$ dan ke atas). Keadaan pohon-pohonnya hampir seluruhnya memiliki banir. Untuk tumbuhan bawah, rata-rata memiliki kerapatan sedang. Dalam pemanenan kayunya alat utama yang digunakan adalah gergaji rantai untuk kegiatan penebangan dan pembagian batang, traktor untuk penyaradan dan pembuatan jalan serta truk trailler untuk pengangkutan kayunya.

Objek dalam penelitian ini adalah kegiatan penebangan yang dilakukan dengan menggunakan gergaji rantai (chain saw) meliputi teknik penebangan dan pembagian batang (bucking) serta keadaan pohon. Peralatan yang digunakan adalah : meteran, pita phi, jam henti (stop watch) serta perlengkapan daftar isian (tally sheet). 


\section{B. Prosedur Penelitian}

Pada dasarnya penelitian ini dilakukan dengan cara membandingkan produk tivitas dan efisiensi pemanenan kayu antara teknik penebangan serendah mungki dengan teknik penebangan konvensional sebagai kontrol. Pengumpulan dat dilakukan dengan menggunakan metode pengukuran langsung di lapangan da pengamatan serta wawancara sebagai data penunjang.

Pengumpulan data dilakukan sebagai berikut :

(1) Menetapkan satu petak tebang yang akan dilakukan penebangan.

(2) Mengukur efisiensi penebangan dan produktivitasnya yang meliputi : nam pohon, tinggi banir, jumlah banir, waktu tebang (pembuangan banir pembuatan takik rebah, pembuatan takik balas dan pembagian batang) pengukuran batang bebas cabang (diameter pangkal, diameter ujung, panjan dan keadaannya) serta pengukuran tinggi tunggak.

(3) Mengumpulkan data penunjang seperti keadaan umum lapangan dan keadaa umum perusahaan dengan cara wawancara serta pengutipan data perusahaan.

Sebagai objek pengamatan adalah jenis pohon perdagangan (komersial) yan ditebang berdiameter $50 \mathrm{~cm}$ dan ke atas, dengan ulangan pengamatan 30 poho untuk teknik penebangan serendah mungkin (meninggalkan tunggak serenda mungkin) dan 30 pohon untuk teknik penebangan konvensional (sebagai kontrol).

\section{Analisis Data}

Volume batang dihitung berdasarkan rumus sebagai berikut :

$$
\mathrm{V}=0,25 \pi \mathrm{D}^{2} \mathrm{~L}
$$

di mana : $V=$ volume batang $\left(\mathrm{m}^{3}\right)$

$\mathrm{L}=$ panjang batang $(\mathrm{m})$

$\mathrm{D}=$ diameter rata-rata $(\mathrm{m})$

diperoleh dengan cara sebagai berikut :

$$
\mathrm{D}=0,5(\mathrm{Dp}+\mathrm{Du})
$$

di mana Dp dan Du masing-masing adalah diameter pangkal dan diameter ujung.

Efisiensi dan produktivitas pemanenan kayu dihitung sebagai berikut :

$\begin{aligned} & \text { Produktivitas } \\ & \left(\mathrm{m}^{3} / \text { menit) }\right.\end{aligned}=\frac{\text { Volume kayu batang bebas cabang yang dipungut }\left(\mathrm{m}^{3}\right)}{\text { Waktu tebang (menit) }}$

Efisiensi $(\%)=\frac{\text { Volume kayu batang bebas cabang yang dipungut }\left(\mathrm{m}^{3}\right)}{\text { Volume kayu batang bebas cabang yang seharusnya dapat dimanfaatkan }\left(\mathrm{m}^{3}\right)} \times 100$

Untuk mengetahui hubungan antara tinggi banir dan diameter pohon denga waktu tebang digunakan analisis regresi berganda dengan model berikut : 


$$
\mathrm{W}=\mathrm{a}+\mathrm{bX1}+\mathrm{cX} 2
$$

di mana : $\mathrm{W}=$ waktu tebang (menit)

$\mathrm{X} 1=$ diameter pohon $(\mathrm{m})$

$\mathrm{X} 2$ = tinggi banir $(\mathrm{m})$

$\mathrm{a}, \mathrm{b}, \mathrm{c}=$ parameter regresi.

Pengolahan data dilakukan dengan pendekatan statistik dengan menghitung nilai rata-rata dan nilai simpangan bakunya.

Data lapangan berupa efisiensi dan produktivitas pemanenan kayu diolah ke dalam bentuk tabulasi dan dibandingkan dengan kontrol dengan menggunakan uji-t.

\section{HASIL DAN PEMBAHASAN}

Hasil pengukuran berupa produktivitas dan efisiensi pemanenan kayu disajikan pada Tabel 1 dan 2.

Tabel 1. Produktivitas dan efisiensi pemanenan kayu dengan teknik penebangan serendah mungkin

Table 1. Productivity and efficiency of wood harvesting by practicing the lowest possible felling technique

\begin{tabular}{|c|c|c|c|c|c|c|c|}
\hline No. & Diameter & $\begin{array}{l}\text { Tinggi } \\
\text { banir } \\
\text { (Buttress } \\
\text { height) } \\
\text { (m) }\end{array}$ & $\begin{array}{c}\text { Waktu } \\
\text { tebang } \\
\text { (Harvesting } \\
\text { time) } \\
\text { (mnt) }\end{array}$ & $\begin{array}{l}\text { Tinggi } \\
\text { tunggak } \\
\text { (Stump } \\
\text { height) } \\
\text { (m) }\end{array}$ & $\begin{array}{l}\text { Panjang batang } \\
\text { bebas cabang } \\
\text { (Clear bole } \\
\text { length) } \\
\text { (m) }\end{array}$ & $\begin{array}{l}\text { Produktivitas } \\
\text { (Productivity) } \\
\left.\text { (m } \mathrm{m}^{3} / \mathrm{mnt}\right)\end{array}$ & $\begin{array}{c}\text { Efisiensi } \\
\text { (Efficiency) } \\
(\%)\end{array}$ \\
\hline 1. & 1 & 0,91 & 27,7 & 0,54 & 16,5 & 0,44 & 84,5 \\
\hline 2. & 0,75 & 0,94 & 22,1 & 0,32 & 22 & 0,39 & 85,2 \\
\hline 3. & 0,8 & 2,03 & 19,4 & 0,42 & 18,8 & 0,43 & 79,3 \\
\hline 4. & 0,95 & 1,03 & 42,8 & 0,56 & 24,2 & 0,38 & 90,4 \\
\hline 5. & 1 & 0,95 & 29,3 & 0,46 & 17,9 & 0,46 & 91,1 \\
\hline 6. & 0,7 & 1,78 & 20,4 & 0,47 & 18,4 & 0,34 & 88,9 \\
\hline 7. & 0,95 & 1,11 & 29,3 & 0,52 & 29,2 & 0,66 & 90 \\
\hline 8. & 0,85 & 0,89 & 19,4 & 0,48 & 19,3 & 0,47 & 79,1 \\
\hline 9. & 0,85 & 0,85 & 20 & 0,46 & 15,5 & 0,37 & 79,8 \\
\hline 10. & 0,85 & 1,22 & 23,1 & 0,45 & 20,3 & 0,45 & 85,3 \\
\hline 11. & 0,8 & 0,68 & 22,6 & 0,42 & 18,2 & 0,34 & 81 \\
\hline 12. & 0,9 & 1,62 & 26,2 & 0,48 & 18,8 & 0,39 & 79,1 \\
\hline 13. & 0,95 & 1,8 & 42,6 & 0,52 & 22,2 & 0,36 & 90,2 \\
\hline 14. & 0,95 & 1,6 & 30 & 0,47 & 24,4 & 0,53 & 86,5 \\
\hline 15. & 0,85 & 1,5 & 19,9 & 0,43 & 17,5 & 0,49 & 90,4 \\
\hline 16. & 0,8 & 1,2 & 16,6 & 0,42 & 16,8 & 0,46 & 86,7 \\
\hline 17. & 0,9 & 1,4 & 30,3 & 0,45 & 18,6 & 0,38 & 90,6 \\
\hline 18. & 0,85 & 1,3 & 26,9 & 0,43 & 18,2 & 0,36 & 87,3 \\
\hline 19. & 0,9 & 2,03 & 23,1 & 0,42 & 18,8 & 0,43 & 79 \\
\hline 20. & 0,9 & 0,89 & 28,1 & 0,48 & 19,3 & 0,39 & 85,5 \\
\hline 21. & 1 & 1,62 & 41,4 & 0,48 & 18,9 & 0,35 & 90,5 \\
\hline 22. & 0,8 & 2 & 19,33 & 0,55 & 16,5 & 0,41 & 84,9 \\
\hline 23. & 0,8 & 1,1 & 20,1 & 0,42 & 16,9 & 0,38 & 84 \\
\hline 24. & 0,9 & 1 & 23,5 & 0,4 & 18,5 & 0,46 & 87 \\
\hline 25. & 0,85 & 1,05 & 26,5 & 0,41 & 17,95 & 0,35 & 85,8 \\
\hline 26. & 0,85 & 0,9 & 20,2 & 0,4 & 19,1 & 0,48 & 85,7 \\
\hline 27. & 0,9 & 1,7 & 23,5 & 0,45 & 19,3 & 0,49 & 86 \\
\hline 28. & 0,75 & 1,2 & 22.2 & 0,43 & 18,8 & 0,34 & 85,9 \\
\hline 29. & 0,75 & 1 & 20,2 & 0,4 & 18,5 & 0,37 & 86,8 \\
\hline 30. & 0,8 & 0,75 & 22,1 & 0,38 & 20,25 & 0,45 & 94,9 \\
\hline $\begin{array}{l}\text { Jumlah } \\
\text { (Sum) } \\
\text { Rata-rata }\end{array}$ & 25,9 & 39,03 & 759,1 & 13,52 & 579,6 & 12,6 & 2581,4 \\
\hline (Average) & 0,86 & 1,301 & 25,3 & 0,45 & 19,32 & 0,42 & 86,1 \\
\hline
\end{tabular}

For. Prod. Res. J. Vol. 13 No. 3 (1995) 
Tabel 1 kolom 7 menyajikan gambaran produktivitas pemanenan kayu dengan teknik penebangan serendah mungkin yang besarnya berkisar antara $0,34-0,66$ $\mathrm{m}^{3} /$ menit dengan nilai rata-rata $0,42 \mathrm{~m}^{3} /$ menit atau setara dengan $25,2 \mathrm{~m} 3 /$ jam. Tabel 2 kolom 7 memperlihatkan gambaran produktivitas pemanenan kayu dengan teknik penebangan konvensional yang besarnya berkisar antara $0,34-0,75 \mathrm{~m} 3 / \mathrm{menit}$ dengan nilai rata-rata $0,48 \mathrm{~m} 3 /$ menit atau setara dengan $28,8 \mathrm{~m} 3 / \mathrm{jam}$. Gayut dengan hasil penelitian ini, Idris, M M dan Soenarno (1991) melaporkan bahwa nilai produktivitas penebangan konvensional $\left(22,9 \mathrm{~m}^{3} / \mathrm{jam}\right)$ adalah lebih besar dibandingkan dengan produktivitas penebangan dengan teknik yang diperbaiki $\left(19,3 \mathrm{~m}^{3} / \mathrm{jam}\right)$.

Dari Tabel 1 kolom 7 dan Tabel 2 kolom 7 dapat dilihat bahwa besarnya produktivitas rata-rata untuk teknik penebangan serendah mungkin $(25,2 \mathrm{~m} 3 / \mathrm{jam})$ adalah lebih rendah dari pada untuk teknik penebangan konvensional $\left(28,8 \mathrm{~m}^{3} / \mathrm{jam}\right)$.

Tabel 2. Produktivitas dan efisiensi pemanenan kayu dengan teknik penebangan konvensional

Table 2. The productivity and efficiency of wood harvesting by practicing conventional felling technique

\begin{tabular}{|c|c|c|c|c|c|c|c|}
\hline No. & Diameter & $\begin{array}{l}\text { Tinggi } \\
\text { banir } \\
\text { (Buttress } \\
\text { height) } \\
\text { (m) }\end{array}$ & $\begin{array}{c}\text { Waktu } \\
\text { tebang } \\
\text { (Harvesting } \\
\text { time) } \\
\text { (mnt) }\end{array}$ & $\begin{array}{l}\text { Tinggi } \\
\text { tunggak } \\
\text { (Stump } \\
\text { height) } \\
\text { (m) }\end{array}$ & $\begin{array}{l}\text { Panjang batang } \\
\text { bebas cabang } \\
\text { (Clear bole } \\
\text { length) } \\
\text { (m) }\end{array}$ & $\begin{array}{l}\text { Produktivitas } \\
\text { (Productivity) } \\
\left(\mathrm{m}^{3} / \mathrm{mnt}\right)\end{array}$ & $\begin{array}{c}\text { Efisiensi } \\
\text { Efficiency) } \\
(\%) \\
\end{array}$ \\
\hline 1. & 1 & 1,7 & 22,3 & 1,7 & 18,3 & 0,5 & 71.1 \\
\hline 2. & 0,75 & 1,2 & 18,2 & 1,2 & 19,8 & 0.42 & 82,2 \\
\hline 3. & 0,8 & 1,6 & 23,4 & 1,6 & 17,4 & 0,34 & 83.1 \\
\hline 4. & 0,9 & 1,1 & 16,8 & 1,1 & 20,9 & 0.6 & 72.3 \\
\hline 5. & 0.7 & 1,5 & 13,1 & 1,5 & 22,5 & 0.57 & 81.1 \\
\hline 6. & 0,85 & 1 & 20,4 & 1 & 16 & 0.4 & 84.4 \\
\hline 7. & 0,95 & 1,4 & 16,2 & 1,4 & 17,6 & 0,75 & 90.1 \\
\hline 8. & 1,05 & 0,9 & 28,9 & 0,9 & 17,1 & 0.46 & 85.5 \\
\hline 9. & 0,7 & 1,3 & 18,2 & 1,3 & 22,7 & 0,37 & 73,1 \\
\hline 10. & 0,85 & 0,8 & 20,1 & 0,8 & 19,2 & 0,49 & 86.6 \\
\hline 11. & 0,75 & 0.95 & 20,4 & 0,95 & 22,05 & 0,37 & 74.1 \\
\hline 12. & 0,8 & 1,05 & 14,8 & 1,05 & 17,95 & 0,49 & 75.7 \\
\hline 13. & 0,9 & 1 & 18,2 & 1 & 17 & 0.58 & 76.1 \\
\hline 14. & 0,95 & 0,75 & 18,6 & 0,75 & 16.25 & 0.57 & 87.8 \\
\hline 15. & 1 & 1,65 & 21.8 & 1,65 & 15,35 & 0.54 & 88.1 \\
\hline 16. & 0,95 & 1,6 & 25,5 & 1,6 & 16,4 & 0.45 & 89,9 \\
\hline 17. & 0,9 & 0,9 & 23,9 & 0,9 & 19,1 & 0.41 & 77,1 \\
\hline 18. & 0,85 & 1 & 18,7 & 1 & 21 & 0,52 & 78 \\
\hline 19. & 0,8 & 0,85 & 20,7 & 0,85 & 20,15 & 0,41 & 80.2 \\
\hline 20. & 0,75 & 2 & 14,6 & 2 & 22 & 0.59 & 81,1 \\
\hline 21. & 0,7 & 2,1 & 14,4 & 2,1 & 22,9 & 0,55 & 82,2 \\
\hline 22. & 0,75 & 0,7 & 14,9 & 0,7 & 18,3 & 0,47 & 83,2 \\
\hline 23. & 0,8 & 1,1 & 18,4 & 1,1 & 19,9 & 0,46 & 84,3 \\
\hline 24. & 0,85 & 1,2 & 21,1 & 1,2 & 15,8 & 0,39 & 85,2 \\
\hline 25. & 0,9 & 0,8 & 21,5 & 0,8 & 17,2 & 0,46 & 86,4 \\
\hline 26. & 0,95 & 1,3 & 27,3 & 1,3 & 17,7 & 0,45 & 91,2 \\
\hline 27. & 0,9 & 1,4 & 31,7 & 1,4 & 19,6 & 0,39 & 92,5 \\
\hline 28. & 0,85 & 1,5 & 17 & 1,5 & 15,5 & 0,45 & 79,2 \\
\hline 29. & 0,8 & 0,9 & 17,3 & 0,9 & 19,1 & 0,41 & 70,6 \\
\hline 30. & 0,75 & 1 & 16,1 & 1 & 18 & 0,47 & 90,2 \\
\hline $\begin{array}{l}\text { Jumlah } \\
\text { (Sum) } \\
\text { Rata-rata }\end{array}$ & 25,45 & 36,25 & 594,5 & 36,25 & 562,75 & 14,33 & 2462.6 \\
\hline (Average) & 0.85 & 1,21 & 19,8 & 1,21 & 18,76 & 0,48 & 82,1 \\
\hline
\end{tabular}

Hasil uji-t untuk membandingkan produktivitas kedua teknik penebangan tersebut adalah $\mathrm{t}$ hitung $=3^{* *}(\mathrm{t}$ tabel $99 \%=2,660)$. Oleh karena itu dapat dikatakan bahwa 
produktivitas antara perlakuan teknik penebangan serendah mungkin dengan teknik penebangan konvensional adalah sangat berbeda nyata. Dengan demikian dapat dikatakan bahwa bila ditinjau dari produktivitasnya saja, maka teknik penebangan konvensional adalah lebih baik dari pada teknik penebangan serendah mungkin.

Hal di atas dapat terjadi karena salah satu faktor penentu produktivitas penebangan adalah waktu tebang. Pada penebangan serendah mungkin, dilakukan pembuangan banir dahulu sebelum penebangan dilakukan. Dengan demikian waktu yang diperlukan untuk membuang banir akan memperpanjang waktu tebang, sehingga produktivitasnya menjadi lebih rendah.

Selain faktor di atas, dapat pula terjadi karena faktor dimensi pohon yang dalam hal ini diameter pohon serta tinggi banirnya. Hasil analisis regresi berganda antara diameter pohon (X1) dan tinggi banir (X2) dengan waktu tebang (W1) untuk teknik penebangan serendah mungkin didapatkan persamaan berikut :

$$
\mathrm{W} 1=-29,2+61,1 \mathrm{X} 1+1,4 \mathrm{X} 2
$$

dengan nilai koefisien korelasi $(\mathrm{R})=71 \%$ dan nilai koefisien determinasi $\left(\mathrm{R}^{2}\right)=$ $50 \%$ serta nilai Fhitung $=14,553^{* *}$ (F tabel $99 \%=5,49$ ). Sedangkan untuk teknik penebangan konvensional persamaan yang didapatkan adalah sebagai berikut :

$$
\mathrm{W} 2=-4,6+28,9 \mathrm{X} 1+0,09 \times 2
$$

dengan nilai koefisien korelasi $(\mathrm{R})=63 \%$ dan nilai koefisien determinasi $\left(\mathrm{R}^{2}\right)=$ $40 \%$ serta nilai Fhitung $=8,727^{* *}(\mathrm{~F}$ tabel $99 \%=5,49)$.

Berdasarkan hasil analisis di atas untuk teknik penebangan serendah mungkin dan konvensional jelas terlihat bahwa waktu tebang (yang sangat mempergaruhi nilai produktivitasnya) dipengaruhi oleh diameter pohon dan tinggi banirnya. Hal ini tampak dari nilai $\mathrm{F}$ hitung untuk kedua teknik penebangan tersebut adalah lebih besar dari pada nilai $\mathrm{F}$ tabelnya pada taraf $99 \%$ yang berarti sangat berbeda nyata. Dengan perkataan lain produktivitas pemanenan kayu akan dipengaruhi oleh diameter pohon dan tinggi banirnya.

Pada Tabel 1 kolom 2 dan 5 dapat dilihat bahwa untuk pohon-pohon dengan kisaran diameter antara $0,7-1 \mathrm{~m}$ dan tinggi banir antara $0,75-2,03 \mathrm{~m}$, tinggi tunggak terendah yang bisa dicapai oleh teknik penebangan serendah mungkin berkisar antara 0,32-0,56 m dengan rata-rata $0,45 \mathrm{~m}$. Sedangkan pada Tabel 2 untuk kolom yang sama, dapat dilihat bahwa untuk pohon-pohon dengan kisaran diameter $0,7-1,05 \mathrm{~m}$ dan tinggi banir antara $0,7-2,1 \mathrm{~m}$, tinggi tunggak terendah yang bisa dicapai oleh teknik penebangan konvensional berkisar antara $0,7-2,1 \mathrm{~m}$ dengan rata-rata $1,21 \mathrm{~m}$.

Tabel 1 kolom 8 memperlihatkan gambaran efisiensi pemanenan kayu dengan teknik penebangan serendah mungkin yang besarnya berkisar antara $79-94,9 \%$ dengan nilai rata-rata $86,1 \%$. Tabel 2 kolom 8 menyajikan gambaran efisiensi pemanenan kayu dengan teknik penebangan konvensional yang besarnya berkisar antara $71,1-92,5 \%$ dengan nilai rata-rata $82,1 \%$. Ini berarti bahwa efisiensi penebangan serendah mungkin adalah lebih tinggi daripada efisiensi penebangan konvensional.

Kemudian dari hasil uji-t untuk membandingkan efisiensi kedua teknik penebangan tersebut di atas, menghasilkan $t$ hitung $=2,912^{* *}(\mathrm{t}$ tabel $99 \%=2,660$ ). Maka dapatlah dikatakan bahwa efisiensi pemanenan kayu antara teknik penebangan serendah mungkin dengan teknik penebangan konvensional adalah berbeda sangat nyata pada taraf $99 \%$. 
Dengan demikian, ditinjau dari efisiensinya, teknik penebangan serendah mungkin adalah lebih baik dari pada teknik penebangan konvensional.

Dari hasil analisis di muka terlihat bahwa teknik penebangan serendah mungkin di satu sisi dapat meningkatkan efisiensi pemanenan kayu yang berarti meningkatkan pemanfaatan kayu rata-rata sebesar $1,28 \mathrm{~m}^{3} /$ pohon, namun disisi lain nilai produktivitasnya menjadi menurun yang rata-rata besarnya penurunan tersebut adalah 3,6 $\mathrm{m} 3 / \mathrm{jam}$. Hal ini dapat terjadi karena dengan teknik penebangan serendah mungkin akan meninggalkan tinggi tunggak rata-rata lebih rendah dari pada teknik penebangan konvensional, yang dapat diartikan volume kayu yang dapat dimanfaatkan menjadi lebih besar. Dengan demikian dapat diharapkan akan memberi dampak positif dalam upaya untuk memasyarakatkan peraturan pemerintah dalam hal penebangan serendah mungkin.

Upaya yang perlu dilakukan agar produktivitas dan efisiensi pemanenan kayu dapat meningkat adalah dengan cara melatih para operator gergaji rantai untuk terbiasa melakukan pembuangan banir terlebih dahulu sebelum melakukan penebangan serta meninggalkan tinggi tunggak serendah mungkin. Dengan terbiasanya operator tersebut, maka diharapkan kasus pecah bontos (barber chair) dapat dihindari sehingga bagian kayu yang dapat dimanfaatkanpun akan bertambah yang selanjutnya dapat meningkatkan efisiensinya.

\section{KESIMPULAN DAN SARAN}

1. Rata-rata nilai produktivitas pemanenan kayu pada teknik penebangan serendah mungkin adalah $25,2 \mathrm{~m}^{3} / \mathrm{jam}$ dan yang konvensional adalah $28,8 \mathrm{~m}^{3} / \mathrm{jam}$. Telah terjadi penurunan produktivitas sebesar $3,6 \mathrm{~m}^{3} / \mathrm{jam}$.

2. Rata-rata nilai efisiensi pemanenan kayu pada teknik penebangan serendah mungkin adalah $86,1 \%$ dan teknik penebangan konvensional adalah $82,1 \%$. Telah terjadi peningkatan pemanfaatan kayu sebesar $1,28 \mathrm{~m}^{3} /$ pohon.

3. Tinggi tunggak terendah yang bisa dicapai dengan teknik penebangan serendah mungkin berkisar antara $0,32-0,56 \mathrm{~m}$ dengan rata-rata $0,45 \mathrm{~m}$ dan yang konvensional berkisar antara 0,7 - 2,1 m dengan rata-rata 1,21 m.

4. Perlunya penerapan peraturan-peraturan di bidang pemanenan kayu, khususnya yang menyangkut teknik penebangan, dilaksanakan dengan disertai sangsi yang tegas dan konsisten.

\section{DAFTAR PUSTAKA}

Direktorat Jenderal Pengusahaan Hutan, 1994. Petunjuk teknis Tebang Pilih Tanam Indonesia (TPTI) pada hutan alam daratan. Departemen Kehutanan, Jakarta.

Idris, M M dan Soenarno, 1991. Produktivitas dan beban kerja operator gergaji rantai, pada kegiatan penebangan pohon berbanir tinggi di hutan alam di Kalimantan Tengah. Jurnal Penelitian Hasil Hutan, Vol. 9 (2), pp. 45-52, Bogor.

Wenger, K. F., 1984. Forestry handbook. 2nd edition. John Wiley \& Sons, Inc, New York, USA. 